\title{
How Different Analysis and Interpolation Methods Affect the Accuracy of Ice Surface Elevation Changes Inferred from Satellite Altimetry
}

\author{
Undine Strößenreuther $^{1}$ (D) Martin Horwath ${ }^{1}$. \\ Ludwig Schröder ${ }^{1,2}$
}

Received: 7 May 2019 / Accepted: 24 December 2019 / Published online: 28 January 2020

(C) The Author(s) 2020

\begin{abstract}
Satellite altimetry has been widely used to determine surface elevation changes in polar ice sheets. The original height measurements are irregularly distributed in space and time. Gridded surface elevation changes are commonly derived by repeat altimetry analysis (RAA) and subsequent spatial interpolation of height change estimates. This article assesses how methodological choices related to those two steps affect the accuracy of surface elevation changes, and how well this accuracy is represented by formal uncertainties. In a simulation environment resembling CryoSat-2 measurements acquired over a region in northeast Greenland between December 2010 and January 2014, different local topography modeling approaches and different cell sizes for RAA, and four interpolation approaches are tested. Among the simulated cases, the choice of either favorable or unfavorable RAA affects the accuracy of results by about a factor of 6, and the different accuracy levels are propagated into the results of interpolation. For RAA, correcting local topography by an external digital elevation model (DEM) is best, if a very precise DEM is available, which is not always the case. Yet the best DEM-independent local topography correction (nine-parameter model within a 3,000 m diameter cell) is comparable to the use of a perfect DEM, which exactly represents the ice sheet topography, on the same
\end{abstract}

$凶$ Undine Strößenreuther

undine.stroessenreuther@tu-dresden.de

Martin Horwath

martin.horwath@tu-dresden.de

Ludwig Schröder

ludwig.schroeder@awi.de

1 Technische Universität Dresden, Institut für Planetare Geodäsie, Dresden, Germany

2 Present Address: Alfred Wegener Institute Helmholtz Centre for Polar and Marine Research, Bremerhaven, Germany 
cell size. Interpolation by heterogeneous measurement-error-filtered kriging is significantly more accurate (on the order of $50 \%$ error reduction) than interpolation methods, which do not account for heterogeneous errors.

Keywords Satellite altimetry $\cdot$ Kriging $\cdot$ Repeat altimetry $\cdot$ Interpolation $\cdot$ Ice sheet

\section{Introduction}

Satellite altimetry is one means of determining mass changes in ice sheets (Shepherd et al. 2018), which are affected by climate change and affect the global sea level. Mass changes are derived from estimations of volume changes combined with firn and ice densities (Shepherd et al. 2012; Hurkmans et al. 2014; Khan et al. 2015; McMillan et al. 2016).

Deriving height changes from satellite altimetry usually involves two steps: local height change determination from repeat altimetry, and subsequent spatial interpolation at unobserved areas, possibly involving smoothing. As the repeated altimeter measurements do not refer to exactly the same position, the local topography has to be accounted for. The repeat altimetry analysis (RAA) approach has been widely used to solve this problem (Legrésy et al. 2006; Flament and Rémy 2012b; Nilsson et al. 2016; Sørensen et al. 2018a; Schröder et al. 2019). However, it is subject to a number of methodological choices in the processing chain. They include the size and arrangement of RAA cells, modeling of seasonal height changes (Sørensen et al. 2011), the use of signal parameters such as leading-edge width or backscatter to model changing signal penetration (Simonsen and Sørensen 2017), and outlier elimination.

The spatial coverage of height change estimates from RAA depends on the orbit geometry and the success of RAA estimates, and is neither homogeneous nor complete. Therefore, subsequent interpolation and filtering is commonly applied. Hurkmans et al. (2012b, 2014) apply ordinary kriging (OK) with spatiotemporal modeling of the underlying process. They also introduce external data of higher resolution to improve the interpolation via external drift. OK is an exact interpolator (Cressie 1993). Exact interpolation is desired when the input values are free of error. This is not the case for height changes derived by RAA. They are the output of a fitting algorithm and are provided with individual uncertainties of the estimate. Uncertainties can be used to refine interpolation, for example, by using heterogeneous measurement-error-filtered kriging (HFK) (Christensen 2011).

Note that the preprocessing of altimetry data, which is not the subject of this investigation, can differ in slope correction and radar waveform retracking algorithms (Hurkmans et al. 2012a; Helm et al. 2014; Nilsson et al. 2016; Sørensen et al. 2018b). This affects positioning and height measurements as well as further derived values such as height change estimates. As a matter of fact, the irregular spatial coverage remains unaffected, and coping with it is the focus of this study.

Various approaches in RAA and interpolation lead to differences in the final height change estimates and their correspondingly derived uncertainties. In RAA, altimetry measurements are jointly processed in a defined area (called a cell). The effect of cell size and related modeling of the underlying local topography on trends in 
height change is investigated. For the subsequent interpolation $\mathrm{OK}$, inverse distance weighting (IDW), filtered kriging (FK) and HFK are applied. These four different interpolation approaches are investigated with respect to the accuracy of the interpolated height changes and the reliability of their uncertainty estimates.

The coastal areas show the highest changes in the elevation of the Greenland Ice Sheet (GIS) (Sørensen et al. 2018a). These areas are covered by CryoSat-2 measurements in interferometric synthetic aperture radar (SARIn) mode. While the low-resolution mode (LRM) has a beam-limited footprint of $20 \mathrm{~km}$ and a pulse-limited footprint of $1.5 \mathrm{~km}$, SARIn mode enhances along-track resolution to $300 \mathrm{~m}$ and uses the across-track angle for measurement attribution (Wingham et al. 2006). Obtaining full spatial coverage of height change in an area with sloped topography in combination with the irregular spatial distribution of RAA height change estimates is challenging. This simulation study is conducted at the eastern margins of the Northeast Greenland Ice Stream (NEGIS), where these circumstances can be reproduced without incorporating additional difficulties such as narrow fjords.

Section 2 introduces the mathematics of RAA and the interpolation algorithms used. Section 3 describes the simulations, including the synthetic data set and processing details. The results are analyzed and discussed in Sect. 4. Section 5 summarizes the results and highlights the effect of RAA parameter choices and the benefits of HFK for subsequent interpolation.

\section{Theory}

\subsection{Repeat Altimetry Analysis}

RAA is a fitting method based on least-squares regression. It uses height measurements $h_{i}$ and the corresponding locations and times in a cell to estimate parameters that describe the underlying spatial and temporal variation in the measured elevations.

$$
h_{i}=\mathrm{Ft}_{i}+\mathrm{Fl}_{i}+\mathrm{Fs}_{i}+\operatorname{res}_{i} .
$$

The components $\mathrm{Ft}_{i}, \mathrm{Fl}_{i}$ and $\mathrm{Fs}_{i}$ describe the dependence on time, location and radar signal return characteristics, respectively. Parameters of these components (as specified below) are estimated by RAA. The resulting residuals between model and observation are depicted in $\operatorname{res}_{i}$. The final choice of the RAA parameter set depends on the satellite track configuration and the measurement properties of the mission used.

The design of the cells can vary (Sørensen et al. 2018a). If the cells are arranged along the subsatellite tracks, rectangular cells that span several consecutive shots along track and the repeat corridor across track are well established (Legrésy et al. 2006; Ewert et al. 2012). In the case of regular grids, both rectangular (McMillan et al. 2014) and circular (Simonsen and Sørensen 2017) cell shapes are commonly used. The latter permit a constant maximum measurement distance to the cell center and are used in this article.

In this study the time dependence in Eq. (1) is characterized by a linear trend $\frac{\mathrm{d} h}{\mathrm{~d} t}$. 


$$
\mathrm{Ft}_{i}=\frac{\mathrm{d} h}{\mathrm{~d} t}\left(t_{i}-t_{0}\right)
$$

Additionally, seasonal elevation variations modeled by a combination of sine and cosine terms can be introduced here (Sørensen et al. 2011).

The location-dependent component models the local topography inside the analyzed cell. A common approach is the fit of a plane (Smith et al. 2009; Sørensen et al. 2015; Schröder et al. 2019)

$$
\mathrm{Fl}_{i}=a_{0}+a_{1} x_{i}+a_{2} y_{i},
$$

where $x_{i}, y_{i}$ are horizontal Cartesian coordinates with their origin in the cell center, and $a_{0}, a_{1}, a_{2}$ are the parameters of the plane. Other local topography models exist, such as the biquadratic model with six parameters,

$$
\begin{aligned}
\mathrm{Fl}_{i}= & a_{0}+a_{1} x_{i}+a_{2} y_{i} \\
& +a_{3} x_{i}^{2}+a_{4} y_{i}^{2}+a_{5} x_{i} y_{i},
\end{aligned}
$$

used by Nilsson et al. (2016), Simonsen and Sørensen (2017) or the nine-parameter model

$$
\begin{aligned}
\mathrm{Fl}_{i}= & a_{0}+a_{1} x_{i}+a_{2} y_{i} \\
& +a_{3} x_{i}^{2}+a_{4} y_{i}^{2}+a_{5} x_{i} y_{i} \\
& +a_{6} x_{i}^{2} y_{i}+a_{7} x_{i} y_{i}^{2}+a_{8} x_{i}^{2} y_{i}^{2},
\end{aligned}
$$

used by Ewert et al. (2012), Wouters et al. (2015). In contrast, the local topography model is reduced to only one parameter, $a_{0}$, when a digital elevation model (DEM) is subtracted beforehand (Sørensen et al. 2011; Helm et al. 2014; Simonsen and Sørensen 2017).

Additional parameters may be useful depending on specific characteristics of the altimeter return signal, which is affected by characteristics of the reflecting surface and volume of firn or ice. For CryoSat-2, by the parameter $d B S$, the effects of time-variable signal penetration with anomalies of backscattered power $b s_{i}-\overline{b s}$ are described.

$$
\mathrm{Fs}_{i}=d B S\left(b s_{i}-\overline{b s}\right) \text {. }
$$

This modeling can be further expanded by involving leading-edge width or trailingedge slope of the signal waveform (Flament and Rémy 2012a; Simonsen and Sørensen 2017), or a bias between ascending and descending satellite tracks (McMillan et al. 2014; Simonsen and Sørensen 2017). However, such interactions between the radar measurements and the uppermost firn layer are complex (Simonsen and Sørensen 2017; Adodo et al 2018) and are not yet fully understood. This study focuses on the analysis of different aspects of spatial sampling. In regions where the topography is sufficiently flat to allow for reliable analysis of such waveforms, the influence of the scattering characteristics acts on significantly larger scales. Therefore, we expect a negligible influence of such parameters on our results and do not further analyse these types of parameters. 
For each cell, all selected parameters are solved for simultaneously in a joint leastsquares adjustment to all measurements $h_{i}$ lying inside this cell. The elevation change parameter $\frac{\mathrm{d} h}{\mathrm{~d} t}$ is the target of this analysis. The RAA approach also provides an a posteriori standard error for $\frac{\mathrm{d} h}{\mathrm{~d} t}$, based on the statistics of the residuals res . $_{i}$.

The choice of the local topography model depends on several considerations. The actual topography of Greenland, which is smooth in the ice sheet interior and rugged at the margins, has to be taken into account. The ability to properly model the topography is also linked to the cell size and the number of observations available. Because of the limited number of observations in smaller cells, the number of topography parameters is restricted, while in larger cells a simple model might not be able to depict the actual local topography. The effect of different cell sizes and local topography models is investigated in this study.

\subsection{Interpolation}

The estimated height changes $\frac{\mathrm{d} h}{\mathrm{~d} t}$ have to be interpolated to obtain values at places where data are missing or RAA could not be solved successfully. The interpolation methods used in this study are all based on the same principle: observations $Z$ at locations $r_{i}$ are used to calculate a new value $Z^{*}$ at a certain location $r_{0}$ by weighted summation (Myers 1991; Cressie 1993; Chilès and Delfiner 2012). In this section, $r$ denotes a two-dimensional position vector.

$$
Z^{*}\left(r_{0}\right)=\sum_{i=1}^{n} \lambda_{i} \cdot Z\left(r_{i}\right)
$$

To derive the weights $\lambda_{i}$, IDW uses only geometric information, while kriging uses a geostatistical approach. Different kriging methods have been developed, based on formulations by D. Krige and G. Matheron (Chilès and Delfiner 2012). This study focuses on OK, FK and HFK. Detailed information about the used kriging methods are given for example by Cressie (1993), Chilès and Delfiner (2012), Christensen (2011).

The number of points used for interpolation depends on the data set and the user's decision. Irregularly distributed observations may lead to distorted results, for example due to unwanted screening (Cressie 1988; Chilès and Delfiner 2012) or spatial biases. Therefore, the surroundings are often divided into a certain number of sectors, selecting observations in each of the sectors to obtain a more uniform distribution. The same applies for variograms (Stosius and Herzfeld 2004).

In the field of geodesy, besides kriging, different least-squares collocation methods are commonly applied, which may also model uncertainties (Nilsson et al. 2015; Sørensen et al. 2018a). These include different treatment of measurement and interpolation errors. This study focuses on interpolation error, although methods such as IDW and OK would need additional uncertainty assessment. Basic agreement between kriging and collocation methods is confirmed (Dermanis 1984), although the individual requirements can differ. Distinguishing these two statistical approaches is outside the scope of this article. 
Previous studies prove the general suitability of the selected methods (Rühaak 2015; Christensen and Berrett 2016; Kang et al. 2017) and provide some comparison results (Chaplot et al 2006; Li and Heap 2011). To the authors' knowledge, HFK has not yet been applied to height changes derived by satellite altimetry.

\subsubsection{Inverse Distance Weighting}

The weights of IDW depend on the normalized distances $d_{i}$ between the locations of the new point $r_{0}$ and the surrounding observations $r_{i}$.

$$
\lambda_{i}=\frac{d_{i}^{-k}}{\sum_{i=1}^{n} d_{i}^{-k}} .
$$

The power $k$ of the distance can be adjusted to any positive value (Webster and Oliver 2007). In this study, a value of 1 is used to model linear dependence.

The uncertainty of interpolation $\sigma_{\text {IDW }}$ can be estimated by error propagation as

$$
\sigma_{\mathrm{IDW}}^{2}=\frac{1}{n-1} \sum_{i=1}^{n} \lambda_{i}\left(Z\left(r_{i}\right)-Z^{*}\left(r_{0}\right)\right)^{2}
$$

Points that have observations retain their observed value, and their interpolation error is set to zero.

\subsubsection{Ordinary Kriging}

Kriging uses a variogram for the calculation of weights $\lambda_{i}$. Variograms describe the inquired process in terms of the second moments of value differences in their dependence to distance $h$. The sample variogram value $\hat{\gamma}$ for distance $d$ can be calculated from the observations by

$$
\hat{\gamma}(d)=\frac{1}{2 n} \sum_{i=1}^{n}\left(Z\left(r_{i}\right)-Z\left(r_{i}+d\right)\right)^{2} .
$$

These values are calculated for several distance classes representing an interval of discrete width. A specific variogram model $\gamma$ is fitted to this sample variogram $\hat{\gamma}$. The characteristic parameters describing it are sill (representing the variance of the process), range (corresponding to the maximum distance at which correlation between the values can be observed) and nugget (a discontinuity at the origin). This discontinuity at distances near zero is caused, for example, by limitations of the sampling density (Chilès and Delfiner 2012).

In the formulation of the kriging system, this modeled function is applied to the distances $d$ between the points involved according to 


$$
\left[\begin{array}{cccc}
\gamma\left(d_{11}\right) & \ldots & \gamma\left(d_{1 n}\right) & 1 \\
\vdots & \ddots & \vdots & \vdots \\
\gamma\left(d_{n 1}\right) & \ldots & \gamma\left(d_{n n}\right) & 1 \\
1 & \ldots & 1 & 0
\end{array}\right]\left[\begin{array}{c}
\lambda_{1} \\
\vdots \\
\lambda_{n} \\
m
\end{array}\right]=\left[\begin{array}{c}
\gamma\left(d_{10}\right) \\
\vdots \\
\gamma\left(d_{n 0}\right) \\
1
\end{array}\right]
$$

This equation system is then solved for the weights $\lambda_{i} . m$ is the Lagrange parameter, which completes the system. Interpolation is then applied according to Eq. (7).

The resulting kriging variance $\sigma_{\mathrm{OK}}^{2}$ at a certain point equals the minimized mean squared error on which the kriging formulation is based (Cressie 1988).

$$
\sigma_{\mathrm{OK}}^{2}=\sum_{i=1}^{n} \lambda_{i} \gamma\left(d_{i 0}\right)+m .
$$

For OK, the value for $\gamma\left(d_{i i}\right)$, that is the variogram value for zero distance, is zero, so that the main diagonal in the matrix of Eq. (11) consists of zeros.

\subsubsection{Filtered Kriging}

In the case of no errors, the nugget of the variogram consists only of microscale variation. For noisy data, an error component has to be considered. The aim is to derive values of the error-free component $T$ from measurements $Z$ corrupted with noise $\epsilon$ (Christensen 2011).

$$
Z(r)=T(r)+\epsilon(r) .
$$

If the variance $\sigma^{2}$ of the error $\epsilon$ is known and assumed to be homogeneously distributed, for example due to known measurement errors, it can be introduced into kriging. Different notations can be found for example at Delhomme (1978), Cressie (1993), Rühaak (2015). Based on Christensen (2011), FK can be expressed as

$$
\left[\begin{array}{cccc}
\gamma\left(d_{11}\right) & \ldots & \gamma\left(d_{1 n}\right) & 1 \\
\vdots & \ddots & \vdots & \vdots \\
\gamma\left(d_{n 1}\right) & \ldots & \gamma\left(d_{n n}\right) & 1 \\
1 & \ldots & 1 & 0
\end{array}\right]\left[\begin{array}{c}
\lambda_{1} \\
\vdots \\
\lambda_{n} \\
m
\end{array}\right]=\left[\begin{array}{c}
\gamma_{10} \\
\vdots \\
\gamma_{n 0} \\
1
\end{array}\right]
$$

with

$$
\gamma_{i 0}=\left\{\begin{array}{cc}
\gamma\left(d_{i 0}\right)-\frac{\sigma^{2}}{2}, & d_{i 0} \neq 0 \\
\frac{\sigma^{2}}{2}, & d_{i 0}=0
\end{array} .\right.
$$

The kriging variance is

$$
\sigma_{\mathrm{FK}}^{2}=\sum_{i=1}^{n} \lambda_{i}\left(\gamma_{i 0}-\frac{\sigma^{2}}{2}\right)+m
$$


This method leads to a filtering of the input data set, so that the values of the observed points are modified, depending on the error variances used. In contrast to $\mathrm{OK}$, the kriging variance at observed points is no longer zero.

\subsubsection{Heterogeneous Measurement-Error-Filtered Kriging}

HFK, which incorporates heterogeneous measurement errors into kriging, was developed by Christensen (2011) and successfully applied, for example, by Christensen and Sain (2012), Christensen and Berrett (2016), Kang et al. (2017). The error variances $\sigma_{i}^{2}$ of the observations are used individually in Eq. (18), after modifying the variogram. The values of the original variogram $\gamma$ are reduced by the mean of the individual error variances $\sigma_{i}^{2}$ of the observations.

$$
\gamma^{*}(d)=\left\{\begin{array}{cl}
\gamma(d)-\frac{1}{n} \sum_{i=1}^{n} \sigma_{i}^{2}, & h \neq 0 \\
0, & h=0 .
\end{array}\right.
$$

The arithmetic mean of the RAA-derived a posteriori errors used in Eq. (17) for HFK variogram adjustment is used in this study as homogeneous error for FK in Eq. (14). It differs between the different RAA calculations.

The newly modeled variogram $\gamma^{*}$ is used in the HFK equation.

$$
\left[\begin{array}{cccc}
\gamma^{*}\left(d_{11}\right) & \ldots & \gamma^{*}\left(d_{1 n}\right)+\frac{\sigma_{1}^{2}+\sigma_{n}^{2}}{2} & 1 \\
\vdots & \ddots & \vdots & \vdots \\
\gamma^{*}\left(d_{n 1}\right)+\frac{\sigma_{n}^{2}+\sigma_{1}^{2}}{2} & \ldots & \gamma^{*}\left(d_{n n}\right) & 1 \\
1 & \ldots & 1 & 0
\end{array}\right]\left[\begin{array}{c}
\lambda_{1} \\
\vdots \\
\lambda_{n} \\
m
\end{array}\right]=\left[\begin{array}{c}
\gamma^{*}\left(d_{10}\right)+\frac{\sigma_{1}^{2}}{2} \\
\vdots \\
\gamma^{*}\left(d_{n 0}\right)+\frac{\sigma_{n}^{2}}{2} \\
1
\end{array}\right]
$$

According to Eq. (17), the variogram value for zero distances is zero. Therefore, the main diagonal of the matrix in Eq. (18) is zero, just as for OK. All other elements of the matrix incorporate the individual error variances.

The kriging variance for HFK is defined analogously to OK.

$$
\sigma_{\mathrm{HFK}}^{2}=\sum_{i=1}^{n} \lambda_{i}\left(\gamma^{*}\left(d_{i 0}\right)+\frac{\sigma_{i}^{2}}{2}\right)+m .
$$

This method leads to a filtering of the input data set. In contrast to FK, the filtering considers the individual uncertainties at the observation points.

\section{Simulation Setup}

In order to assess the different RAA models and interpolation methods, simulations are performed on synthetic data sets. Figure 1 introduces the area investigated in this study. The area of approximately $23,000 \mathrm{~km}^{2}$ covers the lower part of the NEGIS drainage system, based on a slight modification of its delineation by Zwally et al. (2012) (Fig. 1). The main glaciers are Nioghalvfjerdsbræ (79N) and Zacchariæ Isstrøm (ZAC) (cf. 

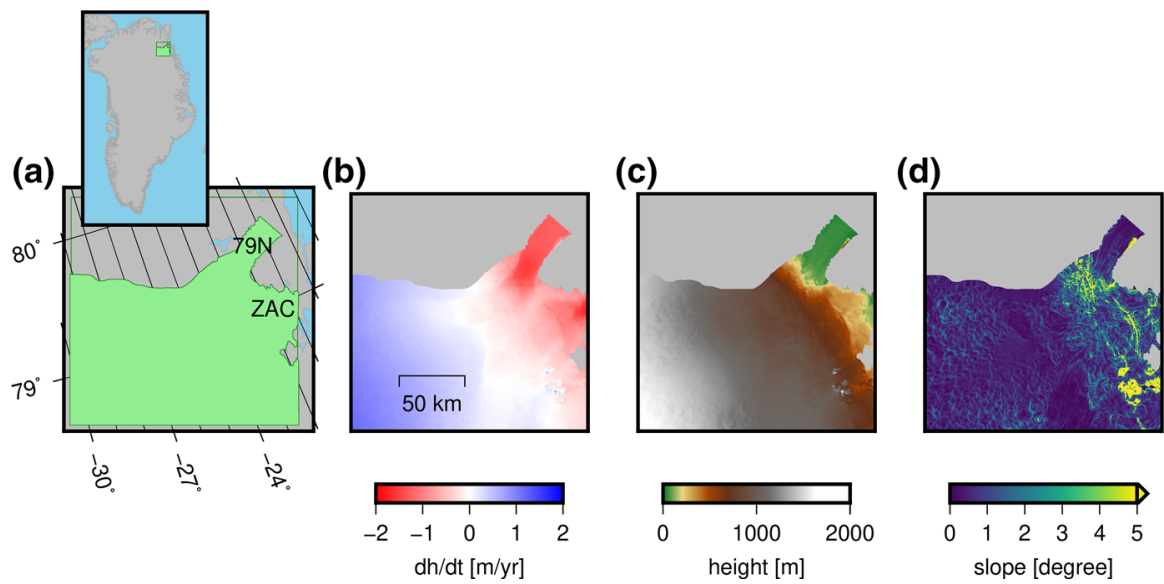

Fig. 1 a Location of synthetic data (green) used in this article and the discussed glaciers Nioghalvfjerdsbræ $(79 N)$ and Zacchariæ Isstrøm (ZAC). b Simulated height changes. c Assumed true topography (TanDEM-X DEM). d Topography-derived slope. All with $100 \mathrm{~m}$ resolution

Fig. 1a). They have shown substantial changes in the past 10 years (Mouginot et al. 2015; Mayer et al. 2018). The CryoSat-2 measurements in this area are mainly in SARIn mode, except for the southwestern corner. The low-resolution mode (LRM) measurements were not included in this study. All geographic data sets and figures are in polar stereographic projection, with $45^{\circ} \mathrm{W}$ as the central meridian (European Petroleum Survey Group Geodesy (EPSG) Code EPSG:3413).

\subsection{Simulation Data}

Several real data sets were combined to obtain an authentic simulated data set. A rate of elevation change (Fig. 1b) is simulated by summing up contributions related to position, flow velocity, elevation and surface mass balance patterns. For each position $i$, height change is simulated as

$$
\frac{\mathrm{d} h}{\mathrm{~d} t}_{i}=b_{0}+b_{1} x_{i}+b_{2} y_{i}+b_{3} v_{i}+b_{4} h_{i}+b_{5} s_{i} .
$$

The terms $b_{0}+b_{1} x_{i}+b_{2} y_{i}$ simulate a component with a simple linear dependence on position. This reflects height loss from southwest to northeast, based on topography and location of the outlet glaciers. The term $b_{3} v_{i}$ creates a trend that depends on ice flow velocity provided by Joughin et al. $(2010 \mathrm{a}, \mathrm{b})$, in order to mimic changes related to ice flow dynamics. $b_{4} h_{i}$ denotes topography-related changes, using the TanDEM-X (TerraSAR-X add-on for Digital Elevation Measurements) DEM (Krieger et al. 2007; Rizzoli et al. 2017). The term $b_{5} s_{i}$ introduces an additional spatial pattern. $s$ is taken as a temporal snapshot of the cumulative surface mass balance anomaly at a certain time from RACMO 2.3 (Regional Atmospheric Climate Model) (Noël et al. 2015). The factors $b_{i}$ balance the different components and adjust the annual height change between $\pm 2 \mathrm{~m} \mathrm{year}^{-1}$. The spatial resolution of this data set can be adjusted. It is 

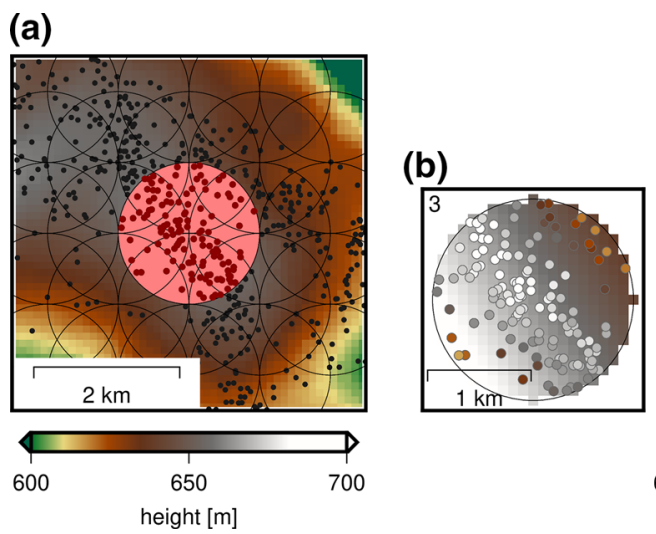

(c)

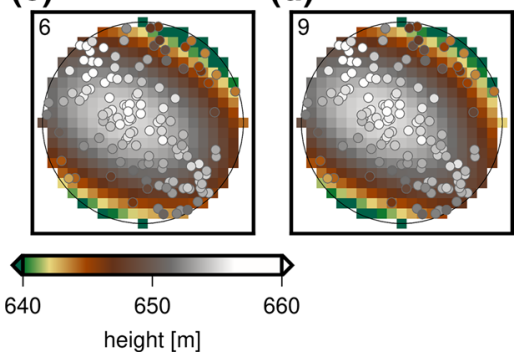

Fig. 2 Illustration of RAA method and local topography modeling. a Distribution of cells (black circles) with 2000 m diameter and the CryoSat-2 measurement locations (gray dots) for a selected area with underlying TanDEM-X DEM. For the red highlighted cell, the modeled local topography using different numbers of parameters (indicated in the top left corner) is shown on the right side, namely $\mathbf{b}$ with three parameters, $\mathbf{c}$ with six and $\mathbf{d}$ with nine parameters. The synthetic CryoSat-2 height measurements are shown in the same color scale

$100 \mathrm{~m}$ for simulated CryoSat-2 measurements, and is adapted to the RAA resolution ( $250 \mathrm{~m}$ to $2500 \mathrm{~m}$ ) for comparisons with RAA results later on.

Locations and times of the actual CryoSat-2 measurements between December 2010 and January 2014 were used for simulation. The measured heights were simulated based on the TanDEM-X DEM (set as initial topography of June 2009) and the synthetic height change rates. A second data set of simulated height measurements is produced by adding simulated errors. The errors are generated as pseudo-random numbers from a uniform distribution between $-c$ and $c$, where the slope-dependent $c$ is defined based on a study of altimetry precision by Schröder et al. (2019) with

$$
c=0.11 \mathrm{~m}+0.79 \cdot \text { slope }^{2} \frac{\mathrm{m}}{\text { degree }^{2}} .
$$

In RAA, these errors are introduced as a priori standard errors for the noisy data.

\subsection{Simulation Procedure}

The simulated height measurements are used as input for RAA, where different choices of RAA cell size and local topography model are assessed. Figure 2 emphasizes the role of local topography in RAA applications. For a selected cell with 2,000 m diameter, the topography of TanDEM-X DEM and three differently parametrized local topography models are compared. As the local topography models are used to reduce the satellite observations to the cell center, model and reality should optimally match.

RAA was applied to both the error-free and the noisy data set, with cell diameters of $500 \mathrm{~m}, 1,000 \mathrm{~m}, 2,000 \mathrm{~m}, 3,000 \mathrm{~m}, 4,000 \mathrm{~m}$ and $5,000 \mathrm{~m}$. Because of the rather short time span and the main focus on the trend of height change, seasonal parameters were not included. The RAA cells are distributed on a regular grid (Helm et al. 2014; 
(a)

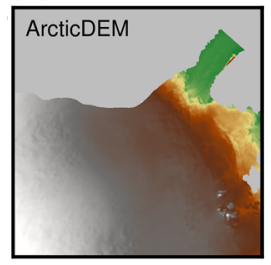

(e)

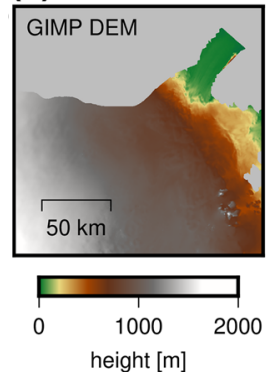

(b)

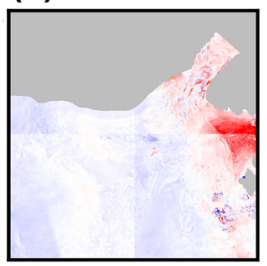

(f)

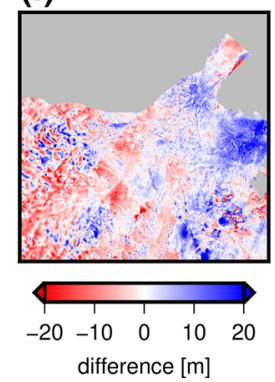

(c)

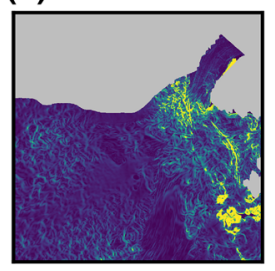

(g)

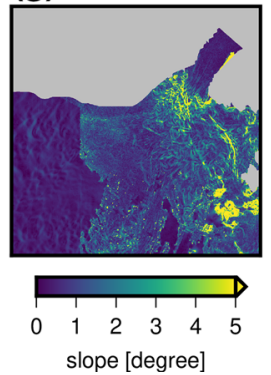

(d)

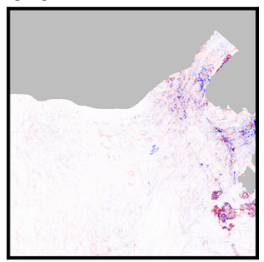

(h)

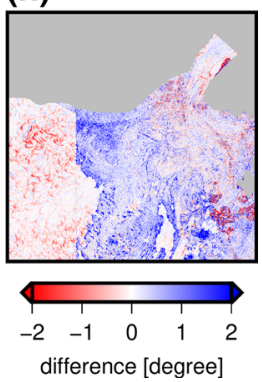

Fig. 3 ArcticDEM (a-d) and GIMP DEM (e-h), restricted to the area of interest. a, e Surface topography, c, $\mathbf{g}$ corresponding slope. $\mathbf{b}, \mathbf{f}$ and $\mathbf{d}, \mathbf{h}$ : differences in the TanDEM-X DEM surface topography and slope, respectively. For the height subtraction in $\mathbf{b}, \mathbf{f}$, the values are mean-adjusted with a mean of $2.687 \mathrm{~m}$ and $-27.143 \mathrm{~m}$, respectively

Schröder et al. 2019; Sørensen et al. 2018a) with overlapping areas (Wouters et al. 2015; Sørensen et al. 2018a). The local topography fit is parametrized using three, six and nine parameters (cf. Eqs. (3-5)), and DEMs are used to subtract the topography in each cell before the height change trend is estimated. The TanDEM-X DEM represents the true surface topography used for simulation, which is usually not available in real data applications. Therefore, additional DEMs were introduced, namely the Greenland Mapping Project (GIMP) DEM (Howat et al. 2014) and the ArcticDEM (Porter et al. 2018). They are likely to be used in actual applications because of their Greenlandwide coverage. The use of TanDEM-X DEM is abbreviated with $\mathrm{T}$ in this article, the GIMP DEM with G and the ArcticDEM with A. The parametrized local topography models are distinguished by the number of parameters, three, six and nine.

Figure 3 depicts the differences between the additional DEMs and the TanDEM-X DEM, which is introduced as the true topography. The DEMs differ in data source and nominal time, but are similar in spatial resolution (about $100 \mathrm{~m}$ ). The mass loss between different height acquisitions leads to different surface heights. After offset removal, the influence of fast-changing surface heights at the outlet glaciers on the different DEMs becomes apparent.

For RAA, the slope is of main interest. The slopes of the ArcticDEM match well those of the TanDEM-X DEM, except for some distinct features. Significant discrepancies occur for the GIMP DEM in some regions, which will influence the RAA results. The reasons for these differences, involving different data acquisition methods and time spans, are not a focus of this article and are therefore not further discussed. 
After RAA, an outlier detection was applied on the resulting parameters. The simulated height changes vary between $-2 \mathrm{~m}$ year $^{-1}$ and $+2 \mathrm{~m} \mathrm{year}^{-1}$. Therefore, absolute height changes exceeding $10 \mathrm{~m}$ year $^{-1}$ are removed. Additionally those with an a posteriori standard deviation of more than $1 \mathrm{~m} \mathrm{year}^{-1}$ are removed. This criterion is commonly applied to RAA results in Greenland (Simonsen and Sørensen 2017) and affects less than $0.1 \%$ of the results. Prior to interpolation, a bicubic function is removed from the original data, in order to reduce the influence of spatial trends on the variogram modeling. This bicubic function was re-added after interpolation.

The gridded elevation trend $\frac{\mathrm{d} h}{\mathrm{~d} t}$ (hereafter denoted $\hat{g}_{i}$ ), derived from synthetic data by applying RAA and further interpolation, is compared with the original synthetic ("true") elevation trend $\left(g_{i}\right)$. The calculation of true values $g_{i}$ is adapted to the spatial resolution at which the estimates $\hat{g}_{i}$ are calculated. That is, for each RAA cell size a data set with true values is calculated based on the data of Eq. (20) in the respective resolution. The differences $g_{i}-\hat{g}_{i}$ are termed true errors.

The accuracy of the results is assessed by the root-mean-square error (RMSE) over all $n$ grid cells.

$$
\mathrm{RMSE}=\sqrt{\frac{\sum_{i=1}^{n}\left(g_{i}-\hat{g}_{i}\right)^{2}}{n}} .
$$

In contrast, the standard uncertainties are defined as the square root of the kriging and interpolation variances.

\section{Results}

\subsection{RAA Performance}

The various cell size and local topography model combinations lead to different RAA results. Figure 4 shows the ratio of grid cells with a successful height change estimate by RAA, dependent on cell size and local topography model and restricted by outlier criteria. Cells without valid RAA results need to be filled by interpolation. The use of noisy versus error-free measurements leads to only a negligible difference with regard to the spatial coverage with RAA results. The size of the RAA cells strongly affect the coverage ratio, as larger cells cover the gaps between subsatellite tracks, while smaller cells adhere more closely to the tracks.

The choice of the local topography model significantly affects the coverage ratio for the $500 \mathrm{~m}$ and $1,000 \mathrm{~m}$ cell sizes. For a diameter of $500 \mathrm{~m}$, increasing the number of parameters from three to six and nine decreases the number of successful estimates dramatically. Here, the number of observations restricts the quality of parameter estimation. As cell size increases, the influence of the local topography model on the success of the height change estimates decreases. For cells with diameters of 3,000, 4,000 , and 5,000 m, the three-parameter model of local topography yields slightly less valid RAA results than the six- and nine-parameter models. The use of DEM subtraction generally leads to more successful height change estimates, especially for the smallest cell size. 


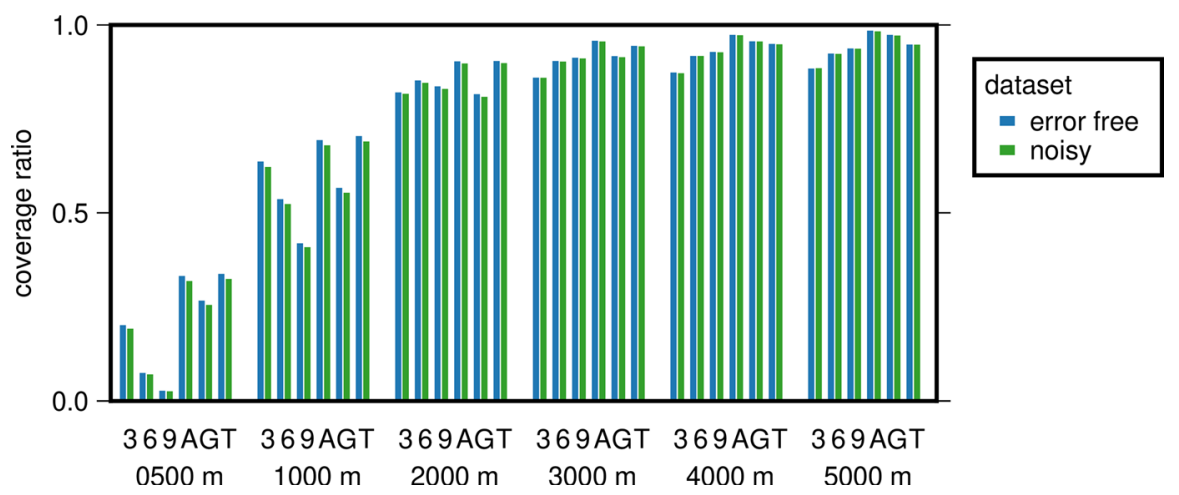

Fig. 4 Ratio of cells with valid RAA results after outlier detection depending on cell size and local topography model. Cell diameter and local topography model are indicated in the lowest and second lowest rows, respectively

The spatial pattern of a posteriori uncertainties reveals a reason for this local topography model-dependent coverage. Figure 5 shows the standard deviations for cells with $3,000 \mathrm{~m}$ diameter. The spatial pattern is related to slope, leading to larger uncertainties in the steep areas, for example near the steeply sloped zone leading into the glacier tongue of $79 \mathrm{~N}$. The more complex the topography modeled, the better the height change estimate and the lower its a posteriori uncertainty. In this investigation, values with an a posteriori RAA-derived standard deviation of more than $1 \mathrm{~m} \mathrm{year}^{-1}$ are rejected (cf. Sect. 3.2). The rejections lead to gaps in the steep areas, depending on the local topography model.

The true errors, $\hat{g}_{i}-g_{i}$, for the selection of Fig. 5 are shown in Fig. 6. Comparison with Figs. 1d and 5 indicates that, similar to the formal uncertainties, the actual errors depend on slope. Striking is the case where the GIMP DEM is used. There, the actual errors are comparably high, even in flat areas. This observation concerning the GIMP DEM subtraction is similar for all cell sizes. The use of TanDEM-X DEM or ArcticDEM leads to both low uncertainties and small actual errors, except for the steepest areas. For the cells with a diameter of $1,000 \mathrm{~m}$ and less, no apparent slopedependent pattern of true error occurs (not shown). These observations apply for both the error-free and the noisy data set.

The standard uncertainties from RAA estimation are compared with the true errors. Figure 7 illustrates a nearly linear relationship between them for RAA cells with at least 3,000 m diameter, which confirms the visual assessment by Figs. 5 and 6. The standard uncertainties slightly overestimate the true errors.

For the cells with diameters of $500 \mathrm{~m}$ to $2,000 \mathrm{~m}$, small standard uncertainties are significantly exceeded by true errors. This is similar for all local topography models, and most pronounced for the GIMP DEM. The difference of this DEM from the simulated topography has a very high effect when small RAA cells are used.

Figure 8 represents the color-coded RMSE information for the different combinations of local topography models, cell sizes and the noisy and error-free data sets. The RMSE spans from 0.13 to $0.85 \mathrm{~m} \mathrm{year}^{-1}$. This is a difference of factor 6.5. The RMSE of the thee-parameter local topography model increases with increasing cell size. The 
(a)

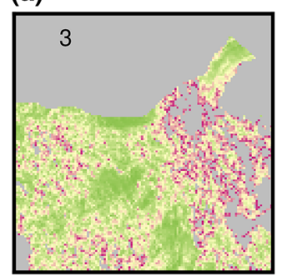

(d)

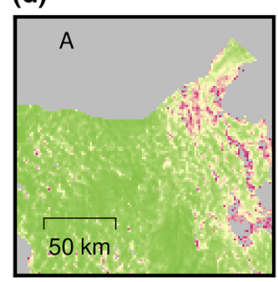

(b)

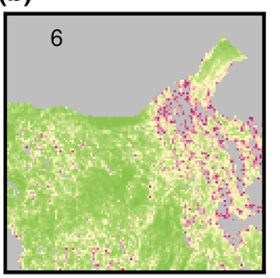

(e)

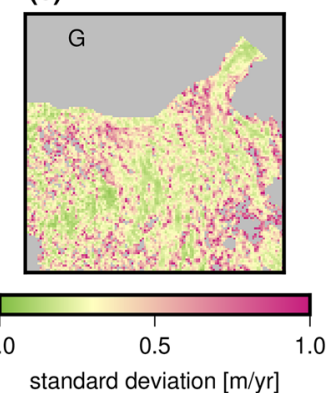

(c)

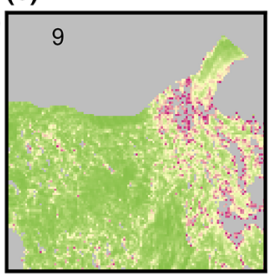

(f)

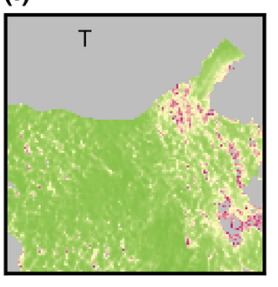

Fig. 5 Standard uncertainty of RAA-estimated height changes, using noisy data and cells with $3,000 \mathrm{~m}$ diameter. The local topography model is indicated in the top left corner
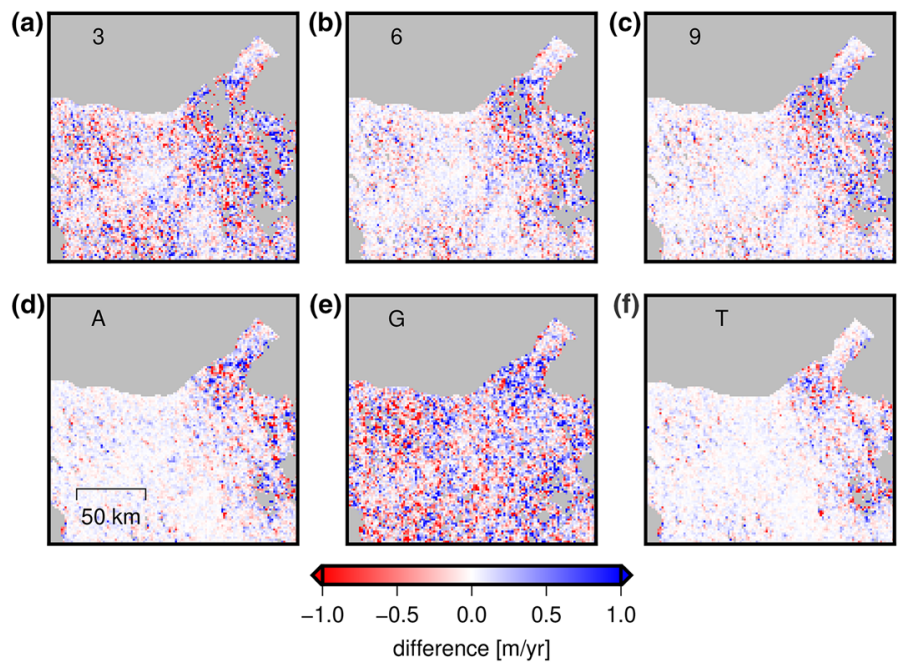

Fig. 6 True error, $\hat{g}_{i}-g_{i}$, of RAA-estimated height changes from noisy data for cells with 3,000 m diameter. The local topography model is indicated in the top left corner

six- and nine-parameter models have the lowest RMSE for cell diameters of 2,000 m and 3,000 m. In contrast, the use of a DEM leads to the best RMSE with large cell diameters. It is striking that the GIMP DEM-reduced RAA shows the worst results among all local topography models. 
(a)

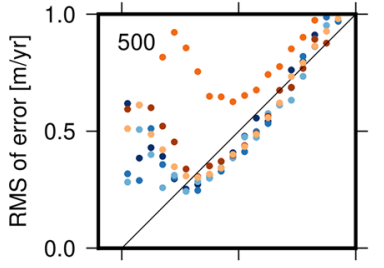

(d)

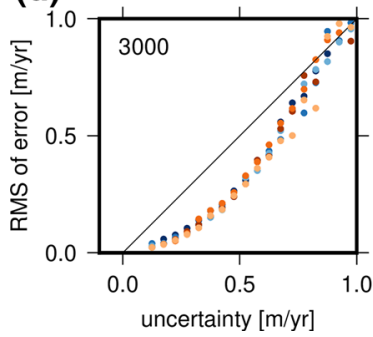

(b)

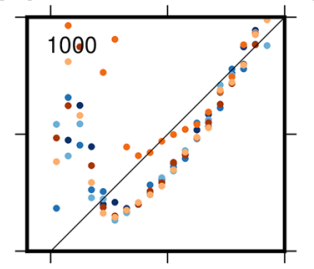

(e)

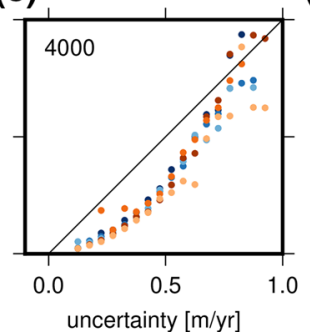

(c)

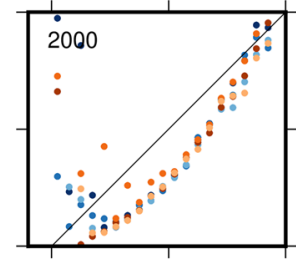

(f)

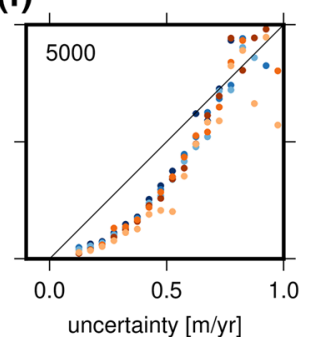

Fig. 7 Relationship between true error (ordinate) and RAA standard uncertainty (abscissa) for noisy data. For clarity, RMS values were calculated over 20 intervals between 0 and $1 \mathrm{~m}_{\text {year }}{ }^{-1}$ of sigma. The RAA cell size is indicated in the top left corner; the local topography models are color-coded
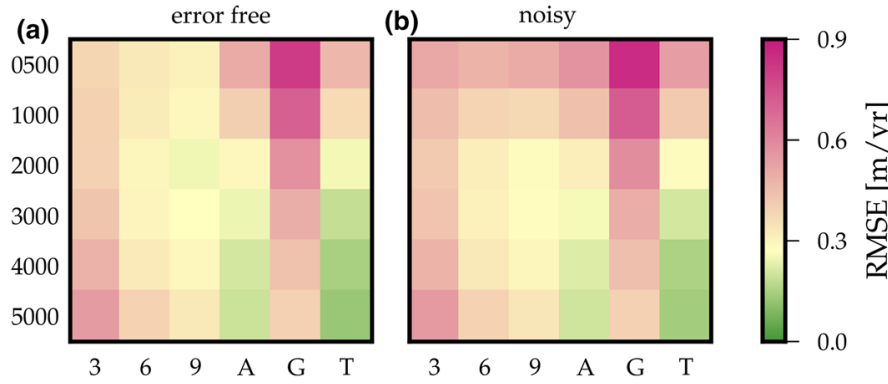

Fig. 8 RMSE for the RAA-derived height change estimates for error-free (left) and noisy (right) data. Cell diameters are indicated on the left, topography models at the bottom

The pseudo-random errors of the noisy data set affect the results and lead to higher RMSE values compared with the error-free data set. The effect of the added noise is strongest for cells with diameters of $2,000 \mathrm{~m}$ and less. Asides from this effect, the noisy and error-free data sets show similar results. The best results are obtained with 5,000 $\mathrm{m}$ cell diameter and the TanDEM-X DEM.

In conclusion, different combinations of cell size and local topography models can lead to satisfactory height change estimates. In the applied specific constellations, cells with diameters of less than 2,000 m do not cope well with perturbations, such as the additional random errors. Larger cells include more observations in the estimation process and therefore are more capable of determining the desired linear height change estimates. If no DEM is used, high parametrized local topography models should be 
preferred over a plane-fit model, as long as a sufficient number of observations are available.

The DEM subtraction leads to good results, as long as the DEM is close to the actual topography. As shown in Fig. 3, the ArcticDEM is close to the assumed true topography of the TanDEM-X DEM. Therefore it leads to better results than the GIMP DEM. The importance of finding suitable DEMs concerning resolution and matching time span has already been addressed by Sørensen et al. (2011) and is well demonstrated here.

As the difference between noisy and error-free height change estimates is not significant, and the assumption of noise is assumed to better reflect the actual situation, further analysis uses the noisy results only.

\subsection{Impact of Variogram Models on Kriging Interpolation}

Before interpolation is applied, the influence of different variograms is analyzed. This analysis is done based on an RAA data set with 2,000 m cell diameter and nine topography parameters. HFK with different variogram selections is applied. The selected RAA result leaves sufficient area for interpolation, so that the effect of different variograms on the kriging result can be properly studied.

Fitting a variogram is an essential part of kriging, as different spatial distances, class divisions, weighting schemes and variogram models have to be considered. The sample variograms were calculated in 30 distance classes (cf. Sect. 2.2.2) ranging from zero to the chosen maximum distance. To fit the models, the different classes were weighted with $p$ depending on sample distance $h$ and number of observations per class $n$ (Pardo-Igúzquiza 1999) as

$$
p=\frac{n}{h^{2}}
$$

Variograms with three options for the maximum distance $(10 ; 50 ; 100 \mathrm{~km})$ and two options for the analytical model (Gaussian and spherical) are considered, which results in a total of six variogram model options. The choice of parameters for variogram modeling depends on the assumptions on the underlying physical processes. Changes in ice heights proceed on small and large scales. However, due to the radar footprint and the coverage with satellite data, as well as the restrictions of RAA, the actual spatial and temporal resolution is limited. The sample variogram can provide different solutions depending on the scales considered. In the process of interpolation, points are selected out of eight sectors, with a maximum of three points per sector. Therefore, correct modeling of the variogram on short distances (depending on the cell size) is of great importance.

The resulting variograms are illustrated in Fig. 9. The shapes of the sample variograms differ slightly according to the spatial scales. The sharp increase at distances up to $3 \mathrm{~km}$ (Fig. 9a) is less pronounced for large maximum distances (Fig. 9c). Further increase of variogram values at more than $70 \mathrm{~km}$ can be neglected, as it exceeds the maximum distance between observation points for interpolation. The largest data gap in the RAA results (at the heavily sloped region inland from the grounding line of ZAC) spans an area of approximately $15 \mathrm{~km}$ times $40 \mathrm{~km}$. 
(a)

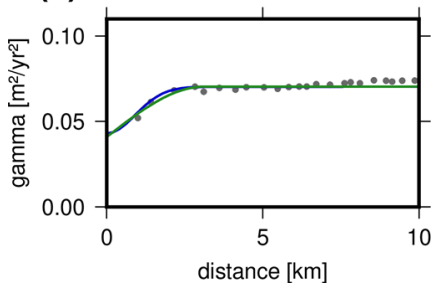

(b)

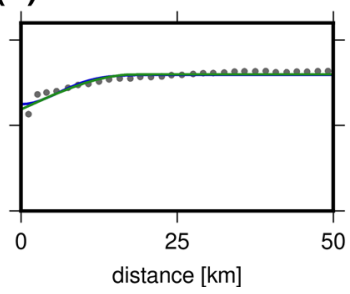

(c)

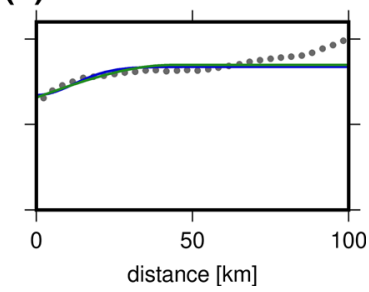

Fig. 9 Variograms of the noisy results with 2,000 $\mathrm{m}$ cell diameter and nine topography parameters, calculated for a maximum difference of $\mathbf{a} 10 \mathrm{~km}, \mathbf{b} 50 \mathrm{~km}$ and $\mathbf{c} 100 \mathrm{~km}$ (note the different distance scales). Sample (black) and fitted Gaussian (blue) and spheric (green) variograms are shown

For further investigation, HFK was applied to the selected RAA data set using the six differently modeled variograms. Here, the focus is on the differences between the results induced by different variogram models. These analyses show that the effect of the choice of variograms on the final HFK result is negligible. The RMSE values differ marginally (e.g. $0.129 \mathrm{~m} \mathrm{year}^{-1}$ to $0.145 \mathrm{~m} \mathrm{year}^{-1}$ for the complete interpolated result).

In contrast, the kriging uncertainty is significantly affected by the choice of the variogram, which thus affects the realism of the uncertainty characterization for the interpolation result. The kriging uncertainty should reflect, in a statistical sense, the true error. In Fig. 10 the kriging uncertainty is plotted against statistics of the true error. Additionally, the underlying number of points per ratio is illustrated as relative density. With a maximum distance of $10 \mathrm{~km}$, a nearly linear relationship is obtained. As an exception, for the lowest uncertainty bin, a strong discrepancy is observed between uncertainty and error. This is caused by just five cells, where the RAA standard uncertainty, that is, the uncertainty of the input to HFK, is significantly underestimated.

The meaningfulness of the kriging uncertainty is best achieved for the fit with a maximum distance of $10 \mathrm{~km}$. The performance of the spheric and Gaussian variogram models is comparable. This investigation shows that the variogram affects mainly the kriging uncertainty, and less the interpolation result. Therefore, the variogram modeling for interpolation of height changes should be focused on short distances. For the following kriging, a spherical variogram model is fitted to sample variograms spanning a maximum distance of $10 \mathrm{~km}$.

\subsection{Interpolation Performance}

Interpolation was applied to the noisy data sets of the RAA results using the four interpolation methods IDW, OK, FK and HFK. The process included the calculation of the sample variogram, the fitting of the model variogram, the calculation of weights and finally the interpolation itself.

The RMSE values for the interpolated height changes are illustrated in Fig. 11. In contrast to IDW and OK, FK and HFK change the values of grid cells that have valid observations. Therefore, grid cells that have no valid value before interpolation are 
(a)

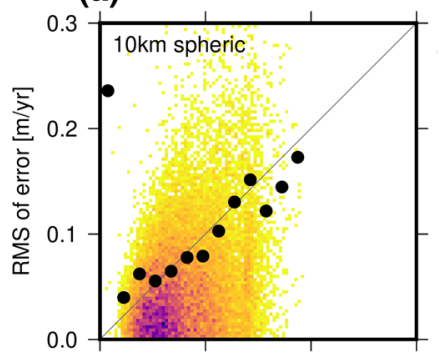

(b) (c)

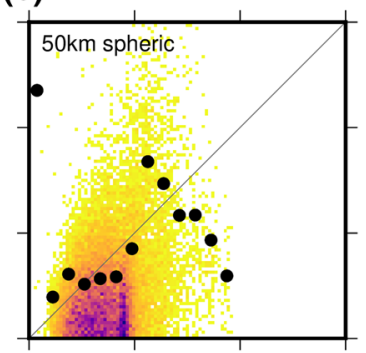

(d) (e)

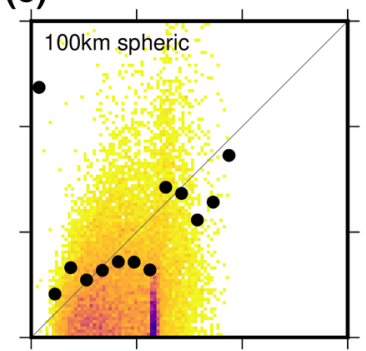

(f)

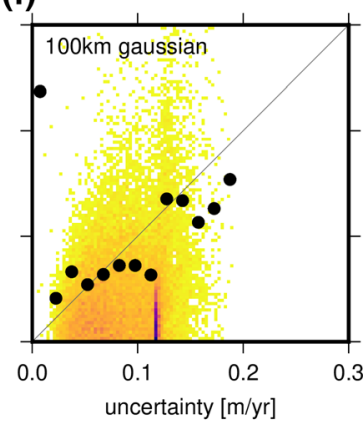

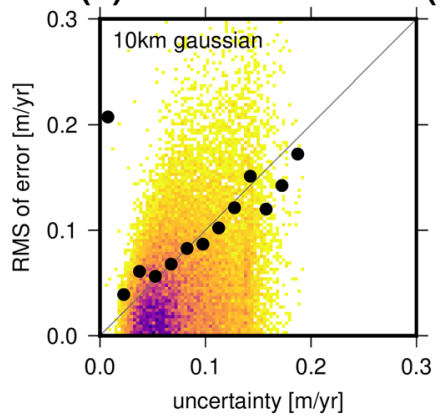
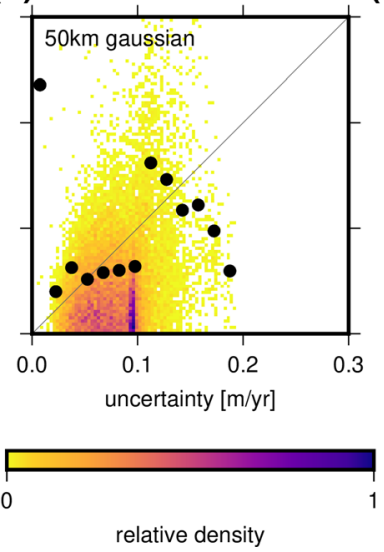

Fig. 10 HFK standard uncertainty (abscissa) is plotted against the true error (ordinate) for different variogram models, applied to the noisy RAA results with 2,000 m diameter and nine topography parameters. For clarity, RMS values (black dots) were calculated over 20 intervals between 0 and $0.3 \mathrm{~m}_{\text {year }}{ }^{-1}$ of sigma. The number of individual values are shown color-coded from many (purple) to fewer (yellow). The specific variogram model and maximum distance are indicated in the top left corner

marked as "interpolated" and the entirety of the grid cells is marked as "complete", while the statistics of the filtered values are marked as "filtered".

For large cell sizes $(4,000 \mathrm{~m} ; 5,000 \mathrm{~m}$ diameter $)$ the RMSE of the complete grid is determined predominantly by the RMSE of the filtered values, rather than by the RMSE of the interpolated values, because of the high coverage of RAA results (cf. Fig. 4).

For IDW, the RMSE of interpolation, shown in Fig. 11b, increases with increasing cell size for the parametrized local topography models. The use of DEMs does not lead to a clear advantage of certain cell sizes in interpolation. The complete result (Fig. 11c) shows increasing RMSE with cell size for the parametrized models and decreasing RMSE with cell size for the DEM subtraction. Compared with the underlying RAA result (see Fig. 11a), the RMSE values are comparable or slightly lower. Notably, for small cell sizes, where many grid cells are interpolated, the RMSE of interpolated values is smaller than that for the original RAA results. This indicates that the weighted averaging process of interpolation reduces noise in the RAA results. The best complete results are achieved with 5,000 m cell diameter and TanDEM-X DEM. 

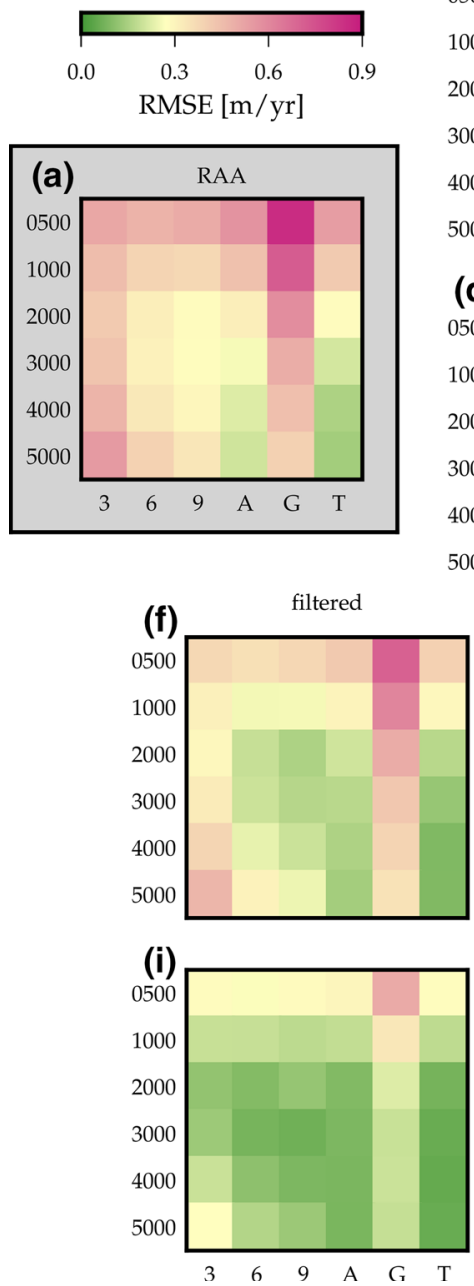

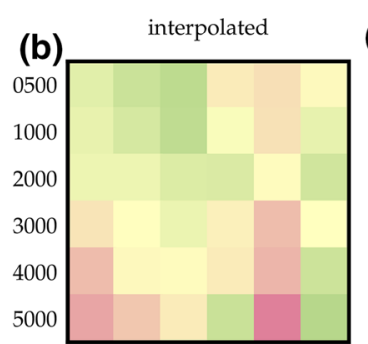

(c) complete

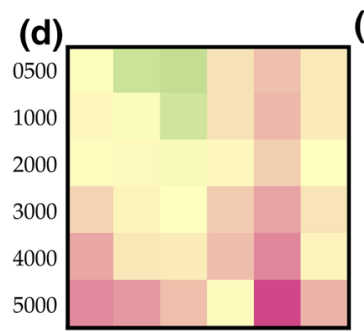

(g)

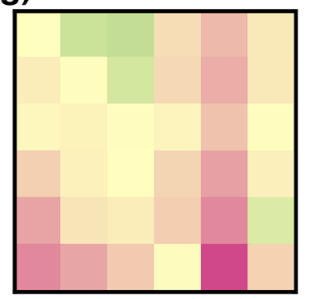

(j)

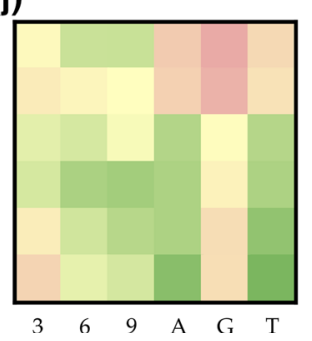

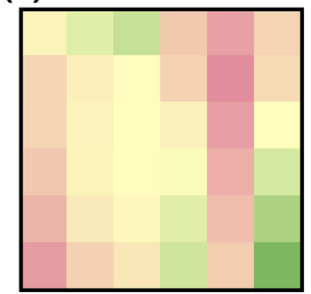

(e)

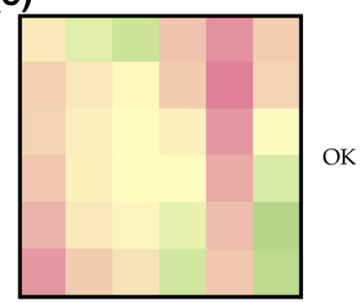

(h)

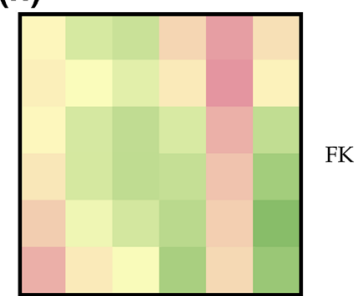

(k)

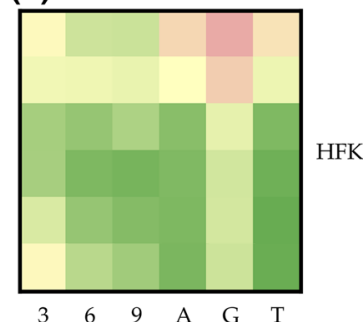

Fig. 11 RMSE after interpolation with IDW (first row), OK (second row), FK (third row) and HFK (last row), distinguished between interpolation (middle) and complete result (right), as well as filtered (left) for FK and HFK. Cell diameters are indicated on the left, topography models at the bottom. The initial RAA result (copy from Fig. 8b) is additionally shown in the top left, to enable comparison

Similar to IDW, the interpolation by OK (Fig. 11d) performs best for small cells and parametrized models or with the TanDEM-X DEM or ArcticDEM and 4,000 m or $5,000 \mathrm{~m}$ cell size. But the RMSE values are higher than for IDW, especially when DEMs are used.

FK (Fig. 11f-h) interpolates similarly to OK, but considers a constant error that is used to filter the observation points. This leads to improved RMSE values at these points, as well as an improved complete result compared with OK and IDW. The 
Table 1 RMSE $\left[\mathrm{m} \mathrm{year}^{-1}\right.$ ] for the noisy data set with 3,000 $\mathrm{m}$ cell diameter and nine-parameter topography model

\begin{tabular}{llll}
\hline & Observed points (filtered) & Interpolation & Complete \\
\hline RAA & 0.279 & & \\
IDW & & 0.242 & 0.276 \\
OK & & 0.271 & 0.278 \\
FK & 0.166 & 0.273 & 0.179 \\
HFK & 0.067 & 0.140 & 0.077 \\
\hline
\end{tabular}

pattern of RAA RMSE is thereby maintained, leading to the best complete results with TanDEM-X DEM and 4,000 m, 5,000 m cell diameters.

For HFK, the filtering of the RAA results improves the RMSE significantly, much more than for FK (cf. Fig. 11i, with Fig. 11a, f). In part, the RMSE decreases by more than $0.3 \mathrm{~m}$ year $^{-1}$ after filtering with HFK (e.g. $500 \mathrm{~m}$ cell diameter and GIMP DEM subtraction). The height change rates best reflecting the simulated truth are achieved with cell diameters of $2,000 \mathrm{~m}$ to $4,000 \mathrm{~m}$ and a local topography correction with six or nine topography parameters or the TanDEM-X DEM or the ArcticDEM.

Table 1 shows the RMSE values for the observation points, interpolation and complete results for a chosen example: the noisy data set with cell diameter of 3,000 m and nine topography parameters. The quality of IDW and OK interpolation is similar, with IDW performing slightly better. FK interpolation performance is similar to OK, but the filtering included at observation points improves the complete result. HFK not only filters better than FK, but in many cases is even able to perform better interpolation, leading to significantly improved complete height change results. The accuracy improvement for this example (3,000 $\mathrm{m}$ cell diameter and nine topography parameters) is $72 \%$ between OK and HFK.

An example of the spatial pattern of the interpolated height changes, differences and standard uncertainties can be seen in Fig. 12. The results of IDW and OK are very similar and show speckled patterns. Their standard uncertainties neglect uncertainties at observation points (value zero) and increase with distance to them. In the interpolated areas, the OK standard uncertainties are generally higher than for IDW, and with less variation. The standard uncertainties are further discussed in Sect. 4.4. FK application leads to a smoother height change result and less error compared with OK. The pattern of uncertainties is similar, but has a fixed value (not zero) at observation points. HFK leads to less error and a much smoother height change result than the other interpolation methods, which is due to the spatially varying filtering. The spatial pattern of the standard uncertainties does not simply reflect the existence of observations, but gives more reliable information about areas with higher uncertainties, which are mainly the sloped regions near the grounding lines of the two glaciers. Additionally, the uncertainties are no longer zero at observation points.

The southwestern corner of the study area is not observed by CryoSat-2 in SARIn mode, but only in LRM mode. The consequent data gap is filled via extrapolation by the different interpolation techniques. OK is not recommended for extrapolation 

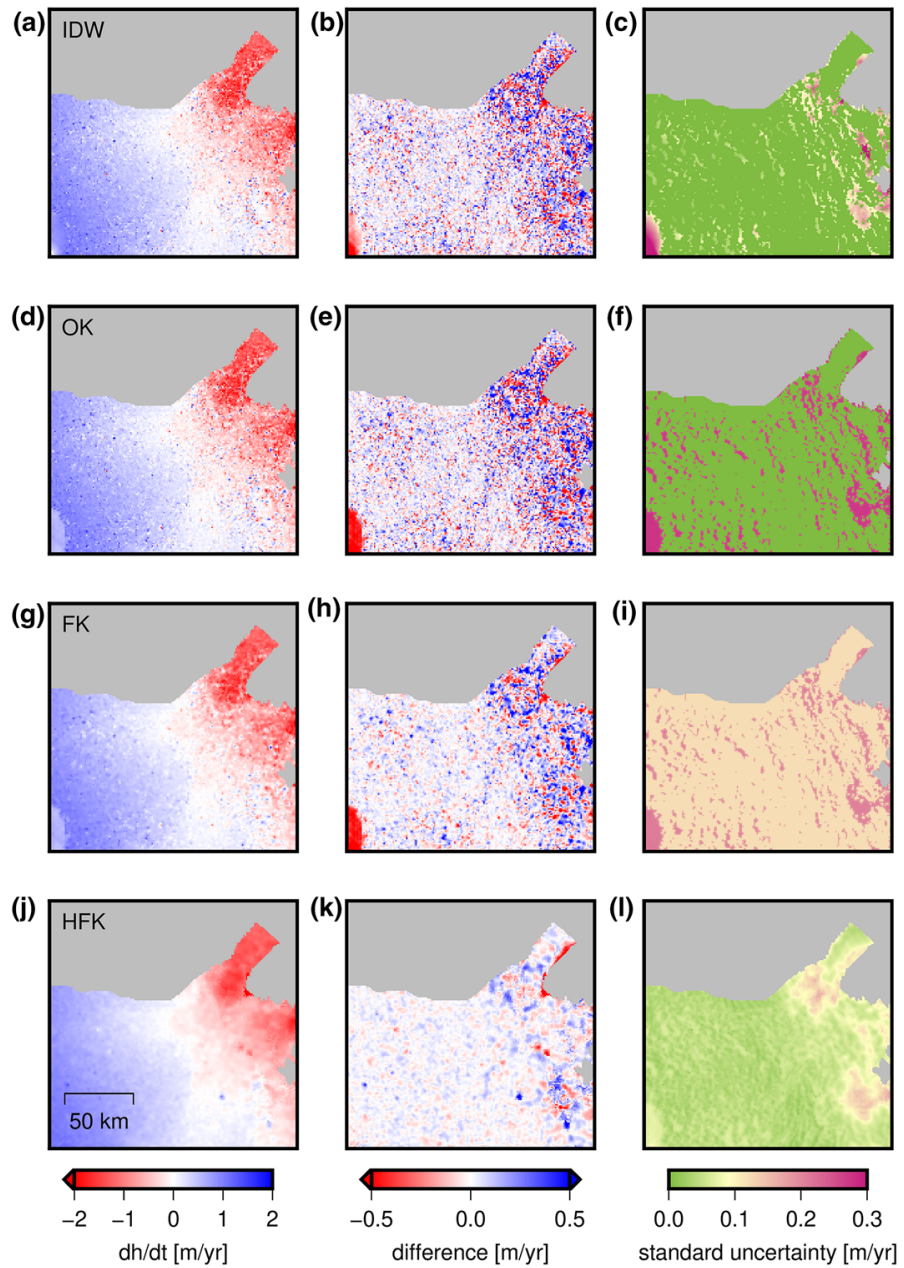

Fig. 12 Resulting height changes (left), true error (center) and standard uncertainties (right) for the noisy data set with 2,000 $\mathrm{m}$ cell diameter and nine-parameter local topography model. The interpolation methods are indicated in the top left corner of the left-hand plots

because the extrapolated values approach the data mean (Chilès and Delfiner 2012). This is reflected in the corresponding higher standard uncertainties. IDW extrapolates slightly better than OK and FK. Although HFK is based on OK, it performs best in extrapolation as well.

The comparison of different interpolation methods shows that HFK is best suited for application to height changes derived from satellite altimetry. In particular, the filtering improves the results substantially. More simple geostatistical methods such as OK do not necessarily outperform other approaches such as IDW. 
(a)
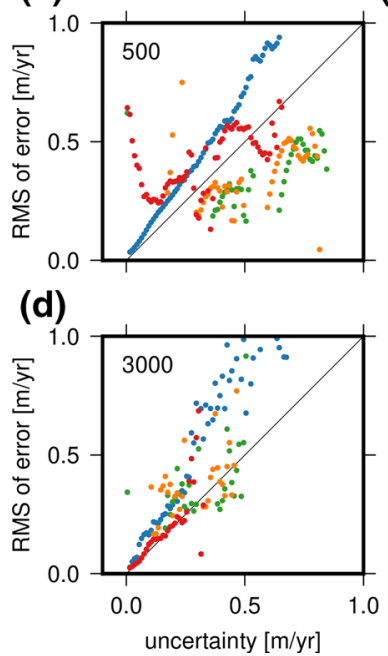

(b)

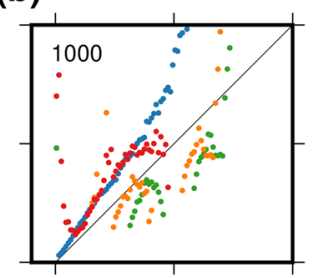

(e)

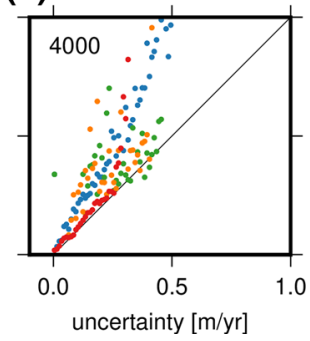

(c)

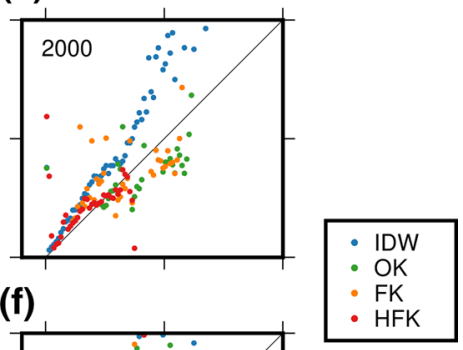

Fig. 13 Relationship between standard uncertainty and true error for the noisy data of the complete result.

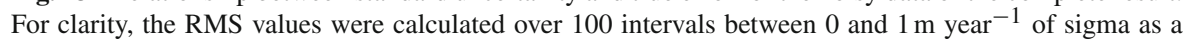
mean of all topography models. The RAA cell sizes are shown in metersin the top left corner

\subsection{Uncertainties}

The kriging standard uncertainties of the four interpolation methods are investigated to obtain more information about their reliability. As in Sects. 4.1 and 4.2, the relationship between true error and the standard uncertainties is analyzed. In Fig. 13, this relationship is shown for all cell sizes and interpolation methods. The focus here is on the distinction between the different interpolation approaches. Therefore, the different topography models are not plotted separately.

IDW has a rather linear relationship, except for the observed points, where the RAA value is maintained and the uncertainty set to zero. The standard uncertainties underestimate the errors.

The inconsistency between error and uncertainties of RAA results observed in Fig. 7 for cells with a diameter of $2,000 \mathrm{~m}$ and less propagate to inconsistencies for OK, FK and HFK uncertainty estimates. This can be seen in Fig. 13a-c, where no simple linear relationship between uncertainties and errors is visible. For cell diameters of $2,000 \mathrm{~m}$ and more, the plotted OK and FK relations are more scattered than those for HFK and IDW. While the uncertainties of OK and FK for cell diameters of 2,000 m and below overestimate the errors, the opposite happens for cell diameters of 3,000 $\mathrm{m}$ and larger. Similar to IDW, the observation points of OK are provided with uncertainty value of zero. FK and OK show very similar behavior in the relationship of error and uncertainty analyzed here.

The HFK uncertainties estimated with data based on cell diameter of at least $3,000 \mathrm{~m}$ represent the actual errors very well up to approximately $0.25 \mathrm{~m}_{\text {year }}{ }^{-1}$. Higher uncertainties underestimate the errors. The best accordance of errors and estimated uncertainties is achieved with HFK for 3,000 $\mathrm{m}$ and 4,000 $\mathrm{m}$ cell diameter. 
This investigation shows that standard uncertainties should be handled with care. The values at observation points for OK and IDW in particular are not meaningful. HFK improves the reliability of the uncertainty estimate.

\section{Conclusions}

To obtain reliable information about the performance of different RAA configurations and interpolation methods, a synthetic data set was created in order to compare the derived height changes with known true values.

It was shown that the RAA results differ depending on the cell size and topography parametrization. In these investigations, the models with six and nine topography parameters lead to good results. The smallest analyzed cell size of $500 \mathrm{~m}$ does not cope well with the induced random errors, while cells with a diameter larger than 4,000 m can lead to larger errors than those with smaller cells. The best results using parametrized models are achieved with a cell diameter of 3,000 m and nine topography parameters. The results of DEM subtraction in RAA depend very much on the quality of the DEM; the more the DEM represents the actual sampled topography, the better the results. ArcticDEM and TanDEM-X DEM (assuming true topography), in conjunction with cells of 3,000 $\mathrm{m}$ and greater diameter, provide the most accurate RAA results among all options tested. As the agreement of the DEM with the topography is difficult to assess when real data is used, DEM subtraction should be applied carefully. The a posteriori standard errors of RAA are reliable for cells with at least 3,000 m diameter, and can be used for filtering with FK and HFK.

The variograms used for kriging focus on short distances, as this gives the best results for interpolation and reliable uncertainties. The subsequent interpolation was accomplished with IDW, OK, FK and HFK. OK and IDW performed comparably well. The resulting height changes are improved by the filtering included in the FK and HFK algorithm. The best results are achieved by incorporating heterogeneous errors with HFK. Additionally, the corresponding standard uncertainties are reliable, and their spatial patterns reflect actual errors.

In this study, linear height change is the parameter of interest. This is a simplification of the real process, as interannual signals are present. They can be resolved by RAA and included in spatiotemporal interpolation.

Further research based on other regions and satellite missions, especially pulselimited radar data, could expand the applicability of these results. Additionally, the influence of outlier criteria and selection of points used for interpolation can be elaborated. Stacked variograms are another approach to cope with the different behavior apparent at different spatial scales that would be worth considering.

Based on these investigations, HFK can be recommended to achieve full spatial coverage of height changes from satellite altimetry measurements derived by RAA, as the results show the smallest error and least speckle, and provide meaningful and reliable uncertainties.

Acknowledgements Open Access funding provided by Projekt DEAL. This work was funded by the German Research Foundation (DFG) (grant: HO-4232/2-1). We thank the German Aerospace Center (DLR) for providing the TanDEM-X Data Products (Proposal ID: DEM_GLAC0671), and the European Space 
Agency for providing the altimetry data products. ArcticDEM was provided by the Polar Geospatial Center under NSF-OPP awards 1043681, 1559691, and 1542736. All figures were made with Generic Mapping Tools (GMT) (Wessel et al. 2013). We thank the two anonymous reviewers and the editor for their comments, which helped to improve the manuscript.

Open Access This article is licensed under a Creative Commons Attribution 4.0 International License, which permits use, sharing, adaptation, distribution and reproduction in any medium or format, as long as you give appropriate credit to the original author(s) and the source, provide a link to the Creative Commons licence, and indicate if changes were made. The images or other third party material in this article are included in the article's Creative Commons licence, unless indicated otherwise in a credit line to the material. If material is not included in the article's Creative Commons licence and your intended use is not permitted by statutory regulation or exceeds the permitted use, you will need to obtain permission directly from the copyright holder. To view a copy of this licence, visit http://creativecommons.org/licenses/ by $/ 4.0 /$.

\section{References}

Adodo F, Remy F, Picard G (2018) Seasonal variations of the backscattering coefficient measured by radar altimeters over the Antarctic Ice Sheet. The Cryosphere 12(5):1767-1778. https://doi.org/10.5194/tc12-1767-2018

Chaplot V, Darboux F, Bourennane H, Leguedois S, Silvera N, Phachomphon K (2006) Accuracy of interpolation techniques for the derivation of digital elevation models in relation to landform types and data density. Geomorphology 77:126-141. https://doi.org/10.1016/j.geomorph.2005.12.010

Chilès JP, Delfiner P (2012) Geostatistics: modeling spatial uncertainty. Wiley series in probability and statistics, 2nd edn. Wiley, Hoboken (ISBN 9781118136188)

Christensen W (2011) Filtered kriging for spatial data with heterogeneous measurement error variances. Biometrics 67(3):947-957. https://doi.org/10.1111/j.1541-0420.2011.01563.x (ISSN 0006341X)

Christensen W, Berrett C (2016) Optimally smoothed maps of pollution source potential via particle backtrajectories and filtered kriging. Chemom Intell Lab Syst 153:1-8. https://doi.org/10.1016/j.chemolab. 2016.02.002 (ISSN 0169-7439)

Christensen W, Sain S (2012) Latent variable modeling for integrating output from multiple climate models. Math Geosci 44(4):395-410. https://doi.org/10.1007/s11004-011-9321-1 (ISSN 1874-8961)

Cressie N (1988) Spatial prediction and ordinary kriging. Math Geol 20(4):405-421. https://doi.org/10. 1007/BF00892986 (ISSN 0882-8121)

Cressie N (1993) Statistics for spatial data, revised edition. Wiley series in probability and statistics. Wiley, Hoboken. https://doi.org/10.1002/9781119115151

Delhomme J (1978) Kriging in the hydrosciences. Adv Water Resour 1(5):251-266. https://doi.org/10. 1016/0309-1708(78)90039-8 (ISSN 0309-1708)

Dermanis A (1984) Kriging and collocation-a comparison. Manuscr Geod 9:159-167

Ewert H, Groh A, Dietrich R (2012) Volume and mass changes of the Greenland ice sheet inferred from ICESat and GRACE. J Geodyn 59-60:111-123. https://doi.org/10.1016/j.jog.2011.06.003 (ISSN 0264-3707)

Flament T, Rémy F (2012a) Antarctica volume change from 10 years of Envisat altimetry. In: Geoscience and remote sensing symposium (IGARSS), 2012 IEEE international, 1848-1851. https://doi.org/10. 1109/IGARSS.2012.6351149

Flament T, Rémy F (2012b) Dynamic thinning of Antarctic glaciers from along-track repeat radar altimetry. J Glaciol 58(211):830-840

Helm V, Humbert A, Miller H (2014) Elevation and elevation change of Greenland and Antarctica derived from CryoSat-2. The Cryosphere 8(4):1539-1559. https://doi.org/10.5194/tc-8-1539-2014 (ISSN 1994-0424)

Howat I, Negrete A, Smith B (2014) The Greenland Ice Mapping Project (GIMP) land classification and surface elevation data sets. The Cryosphere 8(4):1509-1518. https://doi.org/10.5194/tc-8-1509-2014 (ISSN 1994-0424)

Hurkmans R, Bamber J, Davis C, Joughin I, Khvorostovsky K, Smith B, Schoen N (2014) Time-evolving mass loss of the Greenland Ice Sheet from satellite altimetry. The Cryosphere 8(5):1725-1740. https:// doi.org/10.5194/tc-8-1725-2014 (ISSN 1994-0424) 
Hurkmans R, Bamber J, Griggs J (2012a) Brief communication Importance of slope-induced error correction in volume change estimates from radar altimetry. The Cryosphere 6(2):447-451. https://doi.org/10. 5194/tc-6-447-2012

Hurkmans R, Bamber J, Sørensen L, Joughin I, Davis C, Krabill W (2012b) Spatiotemporal interpolation of elevation changes derived from satellite altimetry for Jakobshavn Isbræ. J Geophys Res, Greenland. https://doi.org/10.1029/2011JF002072 (ISSN 0148-0227)

Joughin I, Smith B, Howat I, Scambos T (2010a) MEaSUREs Greenland ice sheet velocity map from InSAR Data, version 1. NASA National Snow and Ice Data Center Distributed Active Archive Center, Boulder, Colorado, USA. https://doi.org/10.5067/MEASURES/CRYOSPHERE/nsidc-0478.001

Joughin I, Smith B, Howat I, Scambos T, Moon T (2010b) Greenland flow variability from ice-sheet-wide velocity mapping. J Glaciol 56(197):415-430. https://doi.org/10.3189/002214310792447734 (ISSN 00221430)

Kang J, Jin R, Li X, Zhang Y (2017) Block kriging with measurement errors: a case study of the spatial prediction of soil moisture in the middle reaches of Heihe River Basin. IEEE Geosci Remote Sens Lett 14(1):87-91. https://doi.org/10.1109/LGRS.2016.2628767 (ISSN 1545-598X)

Khan S, Aschwanden A, Bjørk A, Wahr J, Kjeldsen K, Kjær K (2015) Greenland ice sheet mass balance: a review. Rep Prog Phys 78(4):046801. https://doi.org/10.1088/0034-4885/78/4/046801 (ISSN 00344885)

Krieger G, Moreira A, Fiedler H, Hajnsek I, Werner M, Younis M, Zink M (2007) TanDEM-X: a satellite formation for high-resolution SAR interferometry. IEEE Trans Geosci Remote Sens 45(11):33173341. https://doi.org/10.1109/TGRS.2007.900693 (ISSN 0196-2892)

Legrésy B, Rémy F, Blarel F (2006) Along track repeat altimetry for ice sheets and continental surface studies. In: Proceedings of symposium on 15 years of progress in Radar Altimetry, Venice, Italy, 1318 March 2006, Noordwijk, The Netherlands: European Space Agency Publication Division, eSA-SP no. 614 , paper no. 181

Li J, Heap A (2011) A review of comparative studies of spatial interpolation methods in environmental sciences: performance and impact factors. Ecol Inform 6(3-4):228-241. https://doi.org/10.1016/j. ecoinf.2010.12.003 (ISSN 1574-9541)

Mayer C, Schaffer J, Hattermann T, Floricioiu D, Krieger L, Dodd P, Kanzow T, Licciulli C, Schannwell C (2018) Large ice loss variability at Nioghalvfjerdsfjorden Glacier, Northeast-Greenland. Nat Commun. https://doi.org/10.1038/s41467-018-05180-x (ISSN 2041-1723)

McMillan M, Leeson A, Shepherd A, Briggs K, Armitage T, Hogg A, Kuipers Munneke P, van den Broeke M, Noël B, van de Berg W, Ligtenberg S, Horwath M, Groh A, Muir A, Gilbert L (2016) A highresolution record of Greenland mass balance. Geophys Res Lett 43(13):7002-7010. https://doi.org/ 10.1002/2016GL069666 (ISSN 0094-8276)

McMillan M, Shepherd A, Sundal A, Briggs K, Muir A, Ridout A, Hogg A, Wingham D (2014) Increased ice losses from Antarctica detected by CryoSat-2. Geophys Res Lett 41(11):3899-3905. https://doi. org/10.1002/2014GL060111 (ISSN 0094-8276)

Mouginot J, Rignot E, Scheuchl B, Fenty I, Khazendar A, Morlighem M, Buzzi A, Paden J (2015) Fast retreat of Zachariæ Isstrøm, northeast Greenland. Science 350(6266):1357-1361. https://doi.org/10. $1126 /$ science.aac7111

Myers D (1991) Interpolation and estimation with spatially located data. Chemom Intell Lab Syst 11(3):209_ 228. https://doi.org/10.1016/0169-7439(91)85001-6 (ISSN 0169-7439)

Nilsson J, Gardner A, Sandberg Sørensen L, Forsberg R (2016) Improved retrieval of land ice topography from CryoSat-2 data and its impact for volume-change estimation of the Greenland Ice Sheet. The Cryosphere 10(6):2953-2969. https://doi.org/10.5194/tc-10-2953-2016 (ISSN 1994-0424)

Nilsson J, Sandberg Sørensen L, Barletta V, Forsberg R (2015) Mass changes in Arctic ice caps and glaciers: implications of regionalizing elevation changes. The Cryosphere 9(1):139-150. https://doi. org/10.5194/tc-9-139-2015 (ISSN 1994-0424)

Noël B, van de Berg W, van Meijgaard E, Kuipers Munneke P, van de Wal R, van den Broeke M (2015) Evaluation of the updated regional climate model RACMO2.3: summer snowfall impact on the Greenland Ice Sheet. The Cryosphere 9(5):1831-1844. https://doi.org/10.5194/tc-9-1831-2015 (ISSN 1994-0424)

Pardo-Igúzquiza E (1999) VARFIT: a fortran-77 program for fitting variogram models by weighted least squares. Comput Geosci 25(3):251-261. https://doi.org/10.1016/S0098-3004(98)00128-9 (ISSN 0098-3004)

Porter C, Morin P, Howat I, Noh M-J, Bates B, Peterman K, Keesey S, Schlenk M, Gardiner J, Tomko K, Willis M, Kelleher C, Cloutier M, Husby E, Foga S, Nakamura H, Platson M, Wethington M Jr, 
Williamson C, Bauer G, Enos J, Arnold G, Kramer W, Becker P, Doshi A, D'Souza C, Cummens P, Laurier F, Bojesen M (2018) ArcticDEM. Harvard Dataverse, V1. https://doi.org/10.7910/DVN/ OHHUKH. Accessed 6 Dec 2018

Rizzoli P, Martone M, Gonzalez C, Wecklich C, Borla Tridon D, Bräutigam B, Bachmann M, Schulze D, Fritz T, Huber M, Wessel B, Krieger G, Zink M, Moreira A (2017) Generation and performance assessment of the global TanDEM-X digital elevation model. ISPRS J Photogramm Remote Sens 132:119-139. https://doi.org/10.1016/j.isprsjprs.2017.08.008 (ISSN 0924-2716)

Rühaak W (2015) 3-D interpolation of subsurface temperature data with measurement error using kriging. Environ Earth Sci 73(4):1893-1900. https://doi.org/10.1007/s12665-014-3554-5 (ISSN 1866-6280)

Schröder L, Horwath M, Dietrich R, Helm V, van den Broeke MR, Ligtenberg SRM (2019) Four decades of Antarctic surface elevation changes from multi-mission satellite altimetry. The Cryosphere 13(2):427449. https://doi.org/10.5194/tc-13-427-2019

Shepherd A, Ivins E, Rignot E, Smith B, van den Broeke M, Velicogna I, Whitehouse P, Briggs K, Joughin I, Krinner G, Nowicki S, Payne T, Scambos T, Schlegel N, Agosta C, Ahlstrøm A, Babonis G, Barletta V, Blazquez A, Bonin J, Csatho B, Cullather R, Felikson D, Fettweis X, Forsberg R, Gallee H, Gardner A, Gilbert L, Groh A, Gunter B, Hanna E, Harig C, Helm V, Horvath A, Horwath M, Khan S, Kjeldsen K, Konrad H, Langen P, Lecavalier B, Loomis B, Luthcke S, McMillan M, Melini D, Mernild S, Mohajerani Y, Moore P, Mouginot J, Moyano G, Muir A, Nagler T, Nield G, Nilsson J, Noel B, Otosaka I, Pattle M, Peltier W, Pie N, Rietbroek R, Rott H, Sandberg-Sørensen L, Sasgen I, Save H, Scheuchl B, Schrama E, Schröder L, Seo KW, Simonsen S, Slater T, Spada G, Sutterley T, Talpe M, Tarasov L, van de Berg W, van der Wal W, van Wessem M, Vishwakarma B, Wiese D, Wouters B (2012) A reconciled estimate of ice-sheet mass balance. Science 338(6111):1183-1189. https://doi. org/10.1126/science.1228102 (ISSN 0036-8075)

Shepherd A, Ivins E, Rignot E, Smith B, van den Broeke M, Velicogna I, Whitehouse P, Briggs K, Joughin I, Krinner G, Nowicki S, Payne T, Scambos T, Schlegel N, Agosta C, Ahlstrøm A, Babonis G, Barletta V, Blazquez A, Bonin J, Csatho B, Cullather R, Felikson D, Fettweis X, Forsberg R, Gallee H, Gardner A, Gilbert L, Groh A, Gunter B, Hanna E, Harig C, Helm V, Horvath A, Horwath M, Khan S, Kjeldsen K, Konrad H, Langen P, Lecavalier B, Loomis B, Luthcke S, McMillan M, Melini D, Mernild S, Mohajerani Y, Moore P, Mouginot J, Moyano G, Muir A, Nagler T, Nield G, Nilsson J, Noel B, Otosaka I, Pattle M, Peltier W, Pie N, Rietbroek R, Rott H, Sandberg-Sørensen L, Sasgen I, Save H, Scheuchl B, Schrama E, Schröder L, Seo K, Simonsen S, Slater T, Spada G, Sutterley T, Talpe M, Tarasov L, van de Berg W, van der Wal W, van Wessem M, Vishwakarma B, Wiese D, Wouters B (2018) Mass balance of the Antarctic Ice Sheet from 1992 to 2017. Nature. https://doi.org/10.1038/ s41586-018-0179-y (ISSN 219-222:0028-0836)

Simonsen S, Sørensen L (2017) Implications of changing scattering properties on Greenland ice sheet volume change from Cryosat-2 altimetry. Remote Sens Environ 190:207-216. https://doi.org/10.1016/ j.rse.2016.12.012 (ISSN 0034-4257)

Smith B, Fricker H, Joughin I, Tulaczyk S (2009) An inventory of active subglacial lakes in Antarctica detected by ICESat (2003-2008). J Glaciol 55(192):573-595. https://doi.org/10.3189/ 002214309789470879 (ISSN 0022-1430)

Sørensen L, Simonsen S, Forsberg R, Khvorostovsky K, Meister R, Engdahl M (2018a) 25 years of elevation changes of the Greenland Ice Sheet from ERS, Envisat, and CryoSat-2 radar altimetry. Earth Planet Sci Lett 495:234-241. https://doi.org/10.1016/j.eps1.2018.05.015 (ISSN 0012821X)

Sørensen L, Simonsen S, Langley K, Gray L, Helm V, Nilsson J, Stenseng L, Skourup H, Forsberg R, Davidson M (2018b) Validation of CryoSat-2 SARIn data over austfonna ice cap using airborne laser scanner measurements. Remote Sens 10(9):1354. https://doi.org/10.3390/rs10091354 (ISSN 20724292)

Sørensen L, Simonsen S, Meister R, Forsberg R, Levinsen J, Flament T (2015) Envisat-derived elevation changes of the Greenland ice sheet, and a comparison with ICESat results in the accumulation area. Remote Sens Environ 160:56-62. https://doi.org/10.1016/j.rse.2014.12.022 (ISSN 0034-4257)

Sørensen L, Simonsen S, Nielsen K, Lucas-Picher P, Spada G, Adalgeirsdottir G, Forsberg R, Hvidberg C (2011) Mass balance of the Greenland ice sheet (2003-2008) from ICESat data-the impact of interpolation, sampling and firn density. The Cryosphere 5(1):173-186. https://doi.org/10.5194/tc-5173-2011

Stosius R, Herzfeld U (2004) Geostatistical estimation from radar altimeter data with respect to morphological units outlined by SAR data: application to Lambert Glacier/Amery Ice Shelf. East Antarct Ann Glaciol 39(1):251-255. https://doi.org/10.3189/172756404781814159 (ISSN 0260-3055) 
Webster R, Oliver M (2007) Geostatistics for environmental scientists. Wiley, Hoboken. https://doi.org/10. 1002/9780470517277

Wessel P, Smith W, Scharroo R, Luis J, Wobbe F (2013) Generic mapping tools: improved version released. EOS Trans AGU 94(45):409-410. https://doi.org/10.1002/2013EO450001 (ISSN 0096-3941)

Wingham D, Francis C, Baker S, Bouzinac C, Brockley D, Cullen R, de Chateau-Thierry P, Laxon S, Mallow U, Mavrocordatos C, Phalippou L, Ratier G, Rey L, Rostan F, Viau P, Wallis D (2006) CryoSat: a mission to determine the fluctuations in Earth's land and marine ice fields. Adv Space Res 37:841-871. https://doi.org/10.1016/j.asr.2005.07.027

Wouters B, Martín-Español A, Helm V, Flament T, van Wessem J, Ligtenberg S, van den Broeke M, Bamber J (2015) Dynamic thinning of glaciers on the Southern Antarctic Peninsula. Science 348(6237):899903. https://doi.org/10.1126/science.aaa5727

Zwally H, Giovinetto M, Beckley M, Saba J (2012) Antarctic and Greenland drainage systems. At http:// icesat4.gsfc.nasa.gov/cryo_data/ant_grn_drainage_systems.php. Accessed 15 Dec 2015 